\title{
'Pandemic Diplomacy' and the Politics of Paradox: International Cooperation in the Age of National Distancing
}

\section{'Pandemik Diplomasi' ve Paradoks Politikası: Ulusal Mesafe Çă̆ında Uluslararası İşbirliği}

\author{
Wasiu A. BALOGUN ${ }^{a *}$, Oluwaseun I. SOILE ${ }^{b}$ \\ ${ }^{\text {a }} \mathrm{PhD}$, Lancaster University, Lancaster / UNITED KINGDOM \\ ORCID ID: 0000-0001-8519-2053 \\ ${ }^{\mathrm{b}}$ Researcher, Olabisi Onabanjo University, Ago-Iwoye / NIGERIA \\ ORCID ID: 0000-0002-0047-1684
}

\section{A K A L E B İL G İ İ}

Makale Geçmişi:

Başvuru tarihi: 14 Ağustos 2020

Kabul tarihi: 15 Ekim 2020

Anahtar Kelimeler:

COVID-19,

Diplomasi,

Uluslararası iş birliği,

Milliyetçilik,

Pandemi

\section{A R T ICLE INFO}

Article History:

Received August 14, 2020

Accepted October 15, 2020

\section{Keywords:}

COVID-19,

Diplomacy,

International cooperation,

Nationalism,

Pandemic

\begin{abstract}
Ö Z
Soğuk Savaş'ın sona ermesinden bu yana hiçbir gelişme uluslararası siyasi sistemi COVID-19 salgını kadar etkilememiştir. Bir sağlık krizi uluslararası siyaseti yeniden şekillendiriyor, küresel ekonomiyi baltalıyor, küresel iklim değişikliği görüșmelerini baltalıyor ve diplomaşi için birçok yeni sorun yaratıyor. Paradoksal olarak, dünya, uluslararası seyahat yasaklarının, sınır kapatmaların ve ulusal mesafenin olduğu bir zamanda, bir hastalıkla mücadele için, bir araya geliyor. Başka bir boyutta, milliyetçilik uluslararası iş birliğinin umut sunduğu küresel salgın zamanında enternasyonalizmi gölgede bırakıyor. Salgın, birçok zorluk göz önüne alındığında uluslararası siyaset ve diplomasinin yeni bir düzeninin habercisi olsa da süper güç rekabetinin ve iş birliğinin eski düzenini sürdürmektedir. COVID-19 salgını çözülürken, siyasi ve diplomatik çelişkiler devletler arası ilişkileri güçlendirmekte ve aşı geliştirme umutları ve COVID-19 sonrası dünya düzeninin doğası etrafında belirsizlikler yaratmaktadır. Bu çalışma, COVID-19'un diplomatik uygulamalarını ve salgının patlak vermesinden bu yana küresel politika ve diplomasiyi nasıl șekillendirdiklerini sorgulamayı amaçlamaktadır. Çalışma, COVID-19'un diplomatik ve siyasi bir paradoks olduğunu ve salgının yarattığı güçlüklerin kalıcı olduğunu ve salgın sonrası dönemde küresel siyaset ve diplomasinin yapı taşlarını oluşturacağını savunuyor. Yenilenen hükümetler arası ilişkiler ve iş birlikleri, COVID-19 sonrası küresel refaha giden bir yol sağlayacaktır..
\end{abstract}

\begin{abstract}
A B S T R A C T
Since the end of the Cold War no development has unravelled the international political system as much as COVID-19 pandemic. A health crisis is reshaping international politics, undermining global economy, frustrating global climate change talks, and creating several new challenges for diplomacy. Paradoxically, the world is coming together to combat a disease in a time of international travel bans, border closures and national distancing. In another dimension, nationalism is trumping internationalism in a time of global pandemic, where international cooperation offers hope. While the pandemic heralds a new order of international politics and diplomacy given its many legacies and challenges, it sustains the old order of super power rivalry, competition and cooperation. As COVID-19 pandemic untangles, political and diplomatic contradictions reinforce interstate relations and create uncertainties around the prospects of vaccine development and the nature of postCOVID-19 world order. This study seeks to interrogate diplomatic practices of COVID-19 and how they have shaped global politics and diplomacy since the outbreak of the pandemic. The study argues that COVID-19 is a diplomatic and political paradox, and the challenges created by the pandemic have come to stay and will form the building blocks of global politics and diplomacy in the post pandemic era. Renewed inter-state relations and collaborations will provide a pathway to global prosperity post-COVID- 19 .
\end{abstract}




\section{Introduction}

A healthy nation is a wealthy nation, the saying goes. But the wealth of a nation derives not only from its health but also its economy, politics, military, education, among other sectors. However, a serious health crisis may unleash a devastation of unparalleled magnitude on the wealth and general well-being of any country. This is as much truer for the global community. Global health crisis has shaped the international community in different ways. Pandemics especially, has resulted in the death of millions across the globe, occasioned the demise of states and empires, torpedoed international movements of people and goods, and undermined global governance infrastructure and inter-state relations. History tells us that everyone hundred years the world witnesses a pandemic. From the Marseilles plague of 1720 to the cholera outbreak of 1817-1820 to the Spanish flu of 1918 to the current COVID-19 pandemic, which began in 2019 in the Chinese city of Wuhan, the human community has had to grapple with unimaginable consequences of pandemic outbreaks with each pandemic cycle dwarfing the previous in rapidity, fatality and global reach. But each pandemic cycle has dramatically altered global political landscape especially, rolling back gains in global communications and movements of persons and goods, and inter-state relations. If the Spanish flu of 1918 was facilitated by international maritime trade, the current COVID-19 pandemic is a victim of heightened international air travels, with advances in communication and information technology facilitating seamless inter-state movements of goods, persons and pathogens. Regardless of the means and tools of spread, global pandemics have unravelled the human community with unprecedented challenges as much as they have created opportunities for inter-state cooperation.

COVID-19 is a health crisis, but the crisis manifests in politics and diplomacy. With over half a million death toll already (as at 18 July 2020) according to John Hopkins University COVID-19 datasheet, states have had to initiate and consider important political decisions - shut borders, suspend air travels, roll back on political and diplomatic engagements, and self-isolate- which significantly impact on global politics and diplomacy. Though some countries are gradually relaxing lockdown measures and partially lifting travel bans, the world is still practically on lockdown. As national distancing becomes the new norm, international cooperation is beating a retreat, and nationalism reigns supreme. The socio-economic, political, health, and several other challenges and legacies of the pandemic would require global collaborations through the instrumentality of diplomacy, but it will be interesting to see how such collaborations are fostered at a time of increasing national distancing.

\section{Diplomacy: Meaning, Growth and Development}

Diplomacy is as old as the international political system. As nation-states emerge, membership of the community of nations is conferred through diplomatic recognition, which facilitates exchange of diplomats and commencement of diplomatic relations. The act of managing relations and conducting negotiations among states is the business of diplomats, and the very essence of diplomacy. From being a "process of representation and negotiation" (Padelfold and Lincoln, 1963) to the "application of intelligence and tact" (Satow, 2011) to the "management and methods of representation" (Nicholson, 1988), diplomacy has emerged not only as the mainstay, but the core processes, the means and tools of relations among nations, and the lubricants of the wheels of foreign policy. Much of the world's affairs would not occur, and international relations would not exist, without diplomacy (Manor, 2019). Diplomacy is the platform that brings world leaders together in an attempt to agree on mutual interests or resolve international health crisis such 
as Ebola and Covid-19. Indeed, most countries still have unrestricted access to essential medical needs in this age of coronavirus because of continued international engagements smoothed by diplomacy.

Modern diplomatic practices, which evolved from the post-Renaissance European state system, have changed considerably since the dawn of the twentieth century. From what started strictly as government-to-government business, diplomacy quickly transformed with the advent of three world events; the widespread use of the radio, the Bolshevik Revolution of 1917 and Nazi's political ascendancy and the use of radio as a tool of revolutionary change (ibid). As Russia and Germany circumvented traditional diplomatic government-to-government protocol, nationals of neighbouring countries were brought directly into the domain of diplomacy (ibid). John Hamilton (2020) recants in his book, Manipulating the Mass: Woodrow Wilson and the Birth of American Propaganda, how President Wilson's Committee on Public Information pioneered the idea of public diplomacy during the First World War. Public diplomacy had been born, and it was to dominate much of the twentieth century diplomatic practices.

With innovations in information and communications technology and advent of social media, human interventions yet again significantly altered diplomacy. The speed with which information travels with these developments demands that governments react just as quickly. Doing so meant that governments too had to monitor the information available on social networks. The digitalisation of diplomacy which started with human inventions in the twentieth century is being accelerated by pathogens in the twenty-first century. National distancing orchestrated by global ban on international travels on account of Covid-19 meant that states recourse to online activities, unlocking e-diplomatic opportunities, and revolutionising digital diplomacy in the process. A health crisis, which started 'offline', is unleashing profound impact online, with videoconferencing providing a veritable communication and information infrastructure for diplomacy. Coronavirus is not only creating a new global challenge for international cooperation; it is also providing new frontiers and means to address them.

\section{Covid-19: The Outbreak and Spread}

The history of global health crisis is the story of one hundred years pandemic cycle. History reveals that the world is devastated by a virulent global pandemic nearly every hundred years. The Marseilles plague had claimed 100,000 lives in 1720, followed by the cholera outbreak between 1817 and 1820 which also claimed around one hundred thousand $(100,000)$ lives. The Spanish flu of 1918 resulted in the death of one hundred million $(100,000,000)$ people across the world. In late 2019, a new pandemic broke out in Wuhan, China. From a very humble beginning, the pandemic took on the world with vicious penetration, leaving its trail on the socio-economic, political, medical, etc. devastation of the world. On 30th January 2020, the World Health Organisation (WHO) declared it a Public Health Emergency of International Concern and a pandemic on 11th March 2020. According to data from John Hopkins University, COVID-19 has infected fourteen million, one hundred and nineteen thousand, seven hundred and sixty three $(14,119,763)$ individuals globally, claiming over five hundred and ninety seven thousand, seven hundred and forty one $(597,741)$ lives as at 18 July 2020 with United States, Brazil and United Kingdom accounting for over half of global fatalities (Johns Hopkins University, 2020).

\section{Diplomatic Pratices in the Age of Covid-19}

The coronavirus is a diplomatic game-changer. It presents unique challenges to both the diplomat and the art of diplomacy. As the theatre of diplomatic engagements goes online, the 
diplomat is confronted with significant disruptions to conventional face-to-face diplomatic practices. Yet, a new domain of diplomacy presents enormous opportunities for diplomacy. COVID-19 highlights the huge costs of summits, conferences, and overseas diplomatic missions and embassies, with the possibility of maintaining old diplomatic order in a pandemic-induced global recession. While it may be difficult now to ascertain with finality how far-reaching diplomatic consequences of COVID-19 will be, it is not preposterous to affirm that some of the enchantments and gaieties of the old order of summitry and conferencing are gone for good. As the world fights what U.N. Secretary-General António Guterres calls 'a war against a virus', many diplomats are not under any illusion as to interruptions in their work lives, and the tools and means of discharging their duties. Concepts like 'pandemic diplomacy', 'mask diplomacy', 'pandemic analytics', 'national distancing', and 'travel bans' are suggestive of not only new challenges for states, embassies, and diplomats, but also new means of diplomatic engagements. How has COVID-19 impacted on diplomatic practices?

\section{'Infodemic': Covid-19 and the Politics of Propaganda}

Sun Tzu (544-496 BC), fifth-century Chinese Army General, once said: "all warfare is based on deception"; "'when we are able to attack, we must seem unable; when using our forces, we must appear inactive...." (Tzu, 2007). The underlying message in Tzu's submission found a better expression, centuries later, in Senator Hiram Johnson's address to the United States Congress during the First World War. He remarked: "the first casualty when war comes is truth". Like conventional warfare, the war against coronavirus pandemic has amplified the efficacy of deception and propaganda in diplomatic engagements. With ministries of foreign affairs, embassies and diplomats entangled in the multitude of conflicting conspiracy theories to reinforce a narrative, or as a counter-narrative, the world has an equally vicious plague in 'infodemic'.

The aura of deception and propaganda feeds into the plague of fake news or disinformation and presents a real danger to the fight against COVID-19. Therefore, the war on COVID-19 is both a propaganda and public diplomacy campaign, and both China and the US diplomats and government departments have not failed to make the best of it, to justify preconceived positions and advance specific national objectives. In trying to rescript the narrative on COVID-19, China's approach combines both "white face" (friendly face) and "red face" (hostile face), a paradoxical behaviour premised on dualism in China's strategic culture, and designed to enhance China's global leadership post COVID-19. An aggressive pushback over coronavirus, which has the spokesman of the Chinese foreign ministry Zhao Lijian as the arrowhead, combines digital propaganda and conventional public relations rhetoric in a well-coordinated global megaphone and multipronged effort to reshape global media discourse about the COVID-19 pandemic and effectively overwrite public information about Jinping's government mishandling of the outbreak.

The 'white face' is a soft power diplomacy anchored on providing medical supplies to countries now battling the pandemic, gestures of goodwill described as "mask diplomacy or "medical diplomacy" but suggestive of a strategic gambit to claim the moral high ground and assert international power. China's dual level strategy is anchored on: sharing conspiracy theories about the origins of the virus to strengthen President Xi Jinping and his Communist Party's hold on power while attacking China's adversary, and supporting countries with medical supplies to demonstrate its role as a responsible global power and project a triumphant air (Wong, 2020; Yu and Kaene, 2020). President Xi Jinping is projecting a united, strong and efficient national government- a defence of authoritarianism- and a global leadership alternative superior to Western 
democracies currently struggling to get a handle on the pandemic (Yu and Kaene, 2020; Larsen and Gramer, 2020).

On the other hand, from his initial rhetorical fusillades against China, demonstrated by referring to COVID-19 as "Chinese virus', a purely political tool to prop up his political base in an election year, Trump became more decisive in counteracting Chinese propaganda by asserting that Beijing was slow to alert the world of a virus outbreak. That Trump is reinforcing such a narrative to justify his manifest incompetence in the face of a ravaging pandemic does not deny its veracity. The National Security Adviser, Robert O'Brien (Briant, 2020) accused the WHO of being "'a bit of a propaganda tool for the Chinese", before President Trump's announcement that the White House is putting a hold on the United States' funding of the World Health Organisation, pending an investigation. Even when President Trump transitioned from a lethargic and vacillating approach to a more decisive action on COVID-19, it was clear the US is heavily burdened by leadership deficit in a time of global pandemic. And for a president seeking another term in office, propaganda, conspiracy theories and blame game politics became veritable instruments to prop the image of a commander-in-chief and re-invent the wheel of a country blazing the trail in global developments. Trump's anti-China grandiloquence combines with US medical assistance to Nigeria, Italy and Spain by way of supply of ventilators to fight the scourge of coronavirus, seek to achieve the same duality as President Xi Jinping's 'white face/black face' strategy. But who has had a more effective propaganda? Who has emerged stronger in the race for global relevance in the age of COVID-19?

\section{Pandemic Analytics: Covid-19 and the Politics of Data}

COVID-19 is a data pandemic. As it spreads across the globe, it creates large volumes of data, which multilateral organisations, countries and their representatives are analysing to track the disease, guide responses and find treatments. But big data and its infrastructure can be political. A global pandemic in the age of Artificial Intelligence (AI) creates a context for robotic intelligence database which can be deployed to project national interests, reinforce geopolitics, and amplify existing fault lines in global politics. And with the 5G systems and the capacity to run larger volumes of data across them, greater applications for artificial intelligence (AI) can be developed with significant implications for inter-state relations and diplomacy.

So, in the context of COVID-19, big data are about its creation, use, access, and interpretation; it is about how these critical elements of data are deployed to reinforce national interests and power. With the European Union (EU) creating an open data portal for COVID-19 data (European Data Portal, 2020) and the United States creating the "most extensive collection of machine readable coronavirus literature to date" (US Office of Science and Technology Policy, 2020), COVID-19 has created a new global race for, not nuclear, but data, with the potential to shift geopolitical power dynamics, placing significant leverage on those countries and actors that collect, store, and control data and its infrastructure.

At national levels, COVID-19 data speak different political languages across different countries and systems of government. In communist China, Vietnam and North Korea, COVID-19 data follow same pattern, and evolve from a tightly and centrally controlled political structure anchored on preserving existing political order by moulding public opinion in support of the communist governments thereby eliminating dissents. In the case of China, COVID-19 data manifest duality of purpose; strengthening the communist party's hold on power and projecting the image of a country winning the war against the pandemic- a global public relations agenda to 
enhance global acceptability and reach of the communist system, though vehemently denied by China (Yu and Kaene, 2020). Despite an upward review of Wuhan COVID-19 cases and fatalities in April, there were allegations especially in the United States that China covered up the actual number of infected patients during the initial stage of the outbreak, and that China's expulsion of US journalists was both a decoy and a gambit to cover up the outbreak. Technically, COVID-19 data are more political than medical.

In the realm of diplomacy, COVID-19 data present the global community a new frontier and means for international cooperation and diplomatic engagement. Rising availability, even ubiquity, of COVID-19 data for both state and non-state actors reinforces the conception of public diplomacy with multiple players from across diverse segments of the society. In this shifting landscape, a diplomat becomes a multifaceted personality who subjects data to different interpretations and usage, and data can become the fulcrum of politics, creating or impeding political change and justifying diplomacy (Boyd et al, 2019).

Diplomats have resorted to using big data to address specific COVID-19 related issues, such as concerns around global perception of one's country relative to others in the age of pandemic, the issue of international medical assistance, vaccines development, and evacuation and travel arrangements, among others. Such issues and concerns could feed into anti-COVID-19 measures of states with significant ramifications for foreign policy. When the Japanese Liberal Democratic Party and Ito-Yokado, a Japanese company made a donation of two million Yen and over a million masks, respectively, to China, at the peak of the outbreak in Wuhan (Li \& McEvleen, 2020), it was a diplomatic gesture informed partly by COVID-19 'data' coming out of Wuhan. The decision to invite Cuban medical doctors and nurses to Italy at the peak of the pandemic in the country's worst-affected region, Lombardy, was based, not on COVID-19 incidence, but on its data.

In the two cases, the externalisation of the war against the pandemic was in part informed by geospatial and sensor data, which helped in many aspects including the tracking of regional transmission, management of supply and demand of material resources, rapid mobilisation and deployment of medical resources and personnel, among others. Availability of COVID-19 database, even at its infancy, may offer a more objective, evidence-based foreign policy decision and data-driven diplomacy. And while they may be subjected to states manipulation and control especially in closed or tightly controlled states, and despite being the source of war of words between United States and China in the past weeks, COVID-19 data have engendered international relations, elevated diplomatic discourses, and created new challenges for global governance and diplomacy post-pandemic age.

\section{Covid-19: New Frontier of Diplomacy, Old Order Politics}

As COVID-19 continues its relentless run, the theatre of international cooperation and diplomacy is transitioning from 'offline' to online; from digital to data; from an inherently socially constructed environment to a virtually generated, disentangling old global diplomatic order in ways unparalleled in human history. If human inventions in information and communication technology revolutionised public diplomacy in the twentieth century, 'non-human' creation is taking it a step further in the twenty-first century with significant disruptions to bilateral and multilateral diplomatic means and practices. While many may perceive the disruptions as of little or no consequence, matters of global health and health infrastructure, fragility and susceptibility of global economy, cyber security, data and its infrastructure, artificial intelligence, racism and nationalism 
which the pandemic has spotlighted, will be the anchor of global politics, foreign policy and diplomacy for several years to come.

The rapid scale of the coronavirus has pushed countries to act together while maintaining national distancing, a central aspect of plans to limit the spread of the virus worldwide but which paradoxically redefines the process and means by which that objective is achieved. In what is clearly the new normal, a socially distanced world is reconvening in cyberspace with the help of videoconference technology, providing a new frontier for politicking and creating a new agenda for international diplomacy. The transition from in-person to online diplomatic engagement, characterised by instantaneity and global appeal, is not a deviation from or contradiction of the old political order but a continuation of politics by other means, in a virtually generated political environment. If anything has changed, it is the political environment; not only have both the substance and language of politics remains the same, they have found a new mien and vent in COVID-19.

The pandemic has forced major international organisations to lockdown but has not quarantined politics. From the United Nations to World Trade Organisation (WTO) to International Labour Organisation (ILO), International Maritime Organisation (IMO) and Food and Agriculture Organisation (FAO), multilateral diplomacy is beating a retreat in the face of rising nationalism, and states are compelled to make an online diplomatic switch in order to sustain international cooperation. Though the UN has since rolled back on diplomatic disengagements caused by COVID-19, and the organisation's General Assembly, the world's 'town hall' remains open, critical social elements and practices -the 'middle ground' of diplomacy- associated with a socially-constructed diplomatic environment are missing (Fin, 2020).

Core diplomatic functions of projecting influence, protecting people, and promoting prosperity have not only found new avenues online, they have become the arrowhead of COVID19 politics. And apart from converging online to discuss multilateral or bilateral response mechanisms to the pandemic, the resolve to play old politics is not lost on states. Prime Minister Modi's videoconference call of March 15 where the heads of all eight member states of South Asia Association for Regional Cooperation (SAARC) came together with exception of Pakistan, which designated its State Minister of Health, Zafar Mirza, and which called for a Coronavirus Emergency Fund, serves to promote a collective agenda against the pandemic as much as enhance India's influence in a region increasingly infiltrated by China. China's increased engagement in South Asia poses a threat to India as the regional economic and diplomatic heavyweight (Anderson and Aryes, 2015). Therefore, the call for COVID-19 Fund and an express commitment of ten million dollars by Prime Minister Modi, is part of India's double down outreach across South Asia to counteract China's agenda of "Asia connectivity" being entrenched in the region through its Silk Road 'belt and road' vision (ibid).

Meanwhile, China-India hostility is being renewed with vigour along the Himalayas with the two countries pursuing aggressive military confrontations over territory. So when Modi called for a regional approach against the pandemic, saying: "we can respond best by coming together, not growing apart - collaboration not confusion, preparation not panic" (Indian Prime Minister's Office, 2020), it was more of a call to assert India's leadership while warding off external interests in the region under the guise of the fight against COVID-19 than a change in foreign policy stand for a leader who had, in recent years, shifted focus to other regional groupings that exclude Pakistan, like the Bay of Bengal Initiative for Multi-Sectoral Technical and Economic Cooperation (BIMSTEC), the Bangladesh-Bhutan-India-Nepal (BBIN) grouping, and the Indian Ocean Rim 
Association (IORA) because of hostilities over cross-border terror attacks such as the 2016 Uri attack which led to India's boycott of the $19^{\text {th }}$ Summit of SAARC. Meanwhile, Pakistan saw an opportunity in the virtual COVID-19 SAARC meeting to hit back at India for boycotting the $19^{\text {th }}$ Summit of SAARC which was originally planned to be held in Islamabad, Pakistan, in 2016. A health crisis is not only facilitating and smoothening political relations between age-old rivals, it is doing so in a virtually constructed environment. COVID-19 pandemic may have spotlighted IndiaPakistan old order political rivalry; it has also provided a new frontier for cooperation between the countries.

Like Indo-Pakistan relations, Sino-US relations have found a new outlet in the pandemic, to shape, reshape, and sharpen its rough edges. The relentless power competition between the two countries and the many contradictions in their relations, from trade war to the economic and security concerns resulting in US ban on China's technology giant Huawei in the race for dominance in next generation networks which saw China roll out its 5G networks last November ahead of the United States, have coalesced on COVID-19 to heighten a particularly mistrustful and mutually antagonistic relationship. America's resentment of China has found vigour in President Trump's ruthless push to pin the blame for the outbreak and its spread on China. But an equally effective and indeed more combative pushback from China seems to be trumping Trump's antiChina rhetoric and sentiments.

The pandemic may have put the world in lockdown and torpedoed international cooperation, many of the issues that had upended US-China relations are being projected through COVID-19, online. From the outbreak in Wuhan to data to international humanitarian assistance to quest for vaccines development, COVID-19 is typically political, notwithstanding the human catastrophe it has unleashed. Issues of ethics and morality may be advanced against politicising the pandemic, but "it's impossible to politicise a crisis, because there is nothing more political than how a human society navigates its way through a disaster" (Ramsay, 2020). Ramsay's position is as truer for national politics as it is for international diplomacy. Hence, the pandemic is the latest stage in the endless pursuit of and competition for global dominance between Washington and Beijing, with the virtual environment being the only difference between now and what happened previously. COVID-19 pandemic highlights the need for Sino-American cooperation and, at the same time, reveals the two countries' inability to do so. As much as the pandemic heightens the mistrust between the two superpowers and pushes them further apart, it reinforces the essence of international cooperation, and justifies the need for them to work together to provide global leadership in a time of turbulence.

Beyond US-China relations, the pandemic is unravelling the European Union's relations with both the United States and China. At the moment, the EU finds itself in a strategic conundrum; a choice between the devil and the deep blue sea in its relationship with the two superpowers. Despite criticism of China by senior government officials and politicians in Germany and France two of the block's largest economies for running a "global disinformation campaign to deflect blame for the outbreak of the pandemic and improve its international image", promoting "alternative models of governance" (AFPNews, 2020), lack of openness in information sharing and support for Europe's populists, and her latest assault on Hong Kong, the EU has been reluctant to support Donald Trump's anti-China posture. EU's cautious but sympathetic stand on China may have been informed by the prospect of the unravelling of US-centred globalisation, and China's role in EU's economic recovery between 2007 and 2008 (ibid). China also continued courting Eastern Europe in what has been known as the $17+1$ group. Italy became the first European country 
to sign a 'belt and road' investment memorandum with China, and many European countries individually gave Huawei the go-ahead to run their 5G networks (Pelagidis, 2019). In this equation, Donald Trump seeks to rally the G-7 -and specifically European powers- against China, using the fate of Hong Kong as his cause. The question for European politicians now is how to harness this new awareness to resist China, without tumbling into Trump's cold war (Wintour, 2020). With the United Kingdom government reversing course on Huawei's involvement in the country's 5G networks over national security concerns, a floodgate of mixed feelings over China's telecom giant may have been opened across the EU with the potentials to undo EU-China relations.

At the peak of the outbreak of the coronavirus in Wuhan, the government of Japan, NGOs, Corporations, etc. made donations of protective garments to China. In particular, Japan Youth Development Association (JYDA), dispatched boxes of masks and thermometers to China inscribed with a quote from an ancient Chinese poem: "even though we live in different places, we live under the same sky" (Jozuka and Wang, 2020). A month later, the Jack Ma Foundation reciprocated with a million masks donation to Japan, with mask boxes bearing a quote from the same poem: "stretching before you and me are the same mountains ranges; let's face the same wind and rain together.' (Yu and Keane, 2020). Those poetic exchanges at the borders of Chinese literary history, beyond mere symbolism of goodwill, contextualise, and demonstrate the efficacy of international cooperation in a time of pandemic, and reinforce the significance of soft power diplomacy in international politics. More importantly, they highlight political and diplomatic paradox of global connections in the age of disconnections, as well as the challenges and prospects it presents.

\section{Covid-19, Africa, and the World Powers}

Coronavirus highlights several issues for Africa's international relations. While the pandemic has a global spread, Africa has had a larger share of its asymmetries. From COVID-19propelled xenophobic and racist attacks on Africans in Guangzhou and the failure of WHO to condemn the attacks and bring global attention to it, to WHO-Madagascar political and diplomatic squabble over the country's COVID-19 vaccine claim, to the call for debt relief, to Sino-US involvements in the continent's anti-coronavirus strategy, the pandemic has echoed some of Africa's perennial challenges, while also reinforcing the need for international collaboration to address them.

With inadequate financial capacity, high debt burden and rising debt servicing costs, Africa was already heavily burdened before the outbreak. The collapse of global commodity market at the height of the pandemic and its attendant impact on most African economies put additional pressure on the budgets of governments across the continent with spill-over effects on the health sector. This meant that the health sector was not adequately prepared to respond to the needs of the population during the health crisis and will require significant finance. In response, African countries resorted to contingency fiscal plans and measures, including external borrowing to cushion the impact of sudden freeze in global economic activities, minimise disruptions to cash flow, and ensure that key sectors of the economy stay afloat. Expectedly, on $2^{\text {nd }}$ of April, Africa's Ministers of Finance solicited for debt relief from bilateral, multilateral and commercial creditors in order to "improve their fiscal position and create the fiscal room required for governments to combat the pandemic" (Ekeruche, 2020). The prospects of economic recession loom large across Africa, a development which will further undermine the continent's health sector and its capacity to deal with the pandemic. A health sector deflated by COVID-19 will not only need 'ventilators' to stay alive, it 
will need international cooperation and diplomatic engagements to meet the health needs of the people in a time of pandemic.

Africa's internal difficulties are further compounded by her external predicaments. COVID19 has revealed what it means to be a black in China. Early in April, Chinese authorities in Guangdong province of the southern city of Guangzhou, which has the largest African community in China, began a campaign to forcibly test Africans for the coronavirus, and ordered them to quarantine in designated hotels. As landlords evicted African residents, forcing many to sleep on the street, and hotels, shops, restaurants refused African customers. In what ensued, there were sustained xenophobic and racial attacks on Africans across all divides in the Chinese city of Guangzhou, a development widely condemned by several African leaders, the African Union and the global community. While Chinese pandemic-driven racial clampdown continued at home, China was exploring ways to smoothing relations with Africa. From Jack Ma Foundation and Alibaba to the Chinese engineering giant, China Civil Engineering Construction Corporation (CCECC), China set out to donate consignments of medical equipment to support Africa's war against Coronavirus.

The pandemic may have offered China an opportunity to further cement decades-old relationship with Africa; it has also given Africa every reason to be cautious in her rapprochement with China. From Algeria to Zimbabwe, to Ghana and Kenya, China's offer of help to a continent she has had robust relationship with is being viewed with suspicion and in some cases even unwelcome, a development feeding into Sinophobia across Africa. This realisation may have partly informed the hurriedly packaged Beijing-African Summit on COVID-19 with China's offer of economic incentives and debt forgiveness initiated to smoothen the already tense relationship between China and Africa, and boost Africa's economic recovery post-COVID-19. It remains to be seen whether the latest economic incentives from China can assuage the ill feelings against China especially coming off the back of ill-treatments meted out to Africans in the city of Guangzhou, or whether China's economic stimulus package is a counterforce against US influence in Africa. Is China's COVID-19 African economic recovery package a double edge diplomatic sword?

In another dimension, COVID-19 provides a stage for Sino-US old order politics to be projected in Africa. China's rapprochement with Africa, through the donations of medical equipment, is being counteracted by President Trump's supply of ventilators to two of Africa's most powerful countries - South Africa and Nigeria. Both Trump's ventilators and Jinping's masks are symbolic of soft-power diplomacy and super-power rivalry in a continent which has traditionally been a theatre of proxy super-power wars and confrontations, especially the cold war. The African component of the race for global leadership between China and US is being projected in a time of pandemic and by the pandemic, within and outside the continent. So, when Donald Trump criticised the WHO for overlooking racist attacks on Africans in Guangzhou and for its silence on the issue, in his May 8 letter to the Organisation's Director General, Tedros Ghebreyesus, it was an attack on China through the global governance regime, with the WHO alleged to be "China centric", and China accused of covertly funding WHO to rescript the coronavirus pandemic. And highlighting Africa's plight in the letter also serves the same objective of projecting a ruthless and racist image for Beijing's communist government. Therefore, President Trump simply weaponises the WHO to clip China's rising global profile, while spotlighting her national failings. In this shifting landscape of conflicting national interests, in a time of pandemic, 
the WHO and Africa have become a helpless and hapless pawn in the endless power-play between the US and China.

In another dimension, Africa has had a tenuous relationship with the WHO in a time of pandemic. From Ebola to Corona, Africa's voice in the global health and humanitarian assistance architecture echoes her standing and influence relative to the big spenders. The organisation's relation with Africa has been characterised by belated response in time of crisis and politicisation of vaccine. In the case of Ebola outbreak in West Africa between 2014 and 2016, the WHO response came almost eight months after the pandemic was reported, a development which contributed to the escalation of the crisis and the rapidity of its spread (Dubois et al, 2015). On coronavirus, Africa's relation with the WHO has played out in the organisation's relations with Madagascar over the latter's COVID-19 vaccine claim.

\section{Diplomatic Legacies and Impact of Covid-19 Pandemic}

COVID-19 pandemic is unprecedented, and it is far from over. While the situation continues to evolve, there is already the talk of a 'new normal', which is meant to portray the change in the way people now approach and conduct their daily engagements. Without doubt, coronavirus has thrown up both new challenges and opportunities expected to have far-reaching consequences for diplomatic practices and the conduct of international relations in the years to come. These diplomatic legacies include: the politicisation of global health governance, global economic recession, cyber/digital security challenge, the rising wave of racism and nationalism across the globe and perhaps, the emergence of a China-centric international order.

Politicisation of Global Health Governance: In every sense, COVID-19 pandemic is as much a health crisis as it is political. Unarguably, it is the reinforcement of old-order politics by other means, with the WHO as its fulcrum. Nothing symbolises the politics of COVID-19 than the global health regime led by WHO. Already the battle for the control of the world body has begun. In April, President Donald Trump announced that he would freeze all funding to WHO and could withdraw United States' membership of the organisation. His criticisms and opposition stemmed from his perceived and alleged China-centric response to the COVID-19 pandemic and lack of transparency in sharing information in the wake of the outbreak of the deadly virus in Wuhan late last year. As if looking for an opportune time to take over sponsorship of the world health body, China immediately announced its donation of US\$30 million to WHO. This is the second time China has made such donations to WHO during the pandemic, after it announced a US\$20 million in March (Lo, 2020).

The same scenario played out at the annual decision-making meeting of the World Health Organisation on May 18 where President Xi declared that China was ready to donate US\$2 billion toward fighting the coronavirus and also dispatch doctors and medical supplies to Africa and other developing countries around the world. The donation, to be released over two years, will catapult China to the forefront of international efforts to contain a disease that has claimed more than five hundred thousand $(500,000)$ lives to date, and will amount to more than double what the U.S. had been giving the global health agency before President Trump cut off American funding. This has elicited spate of venomous criticisms from the U.S. who sees this gesture as a desperate effort by Beijing to deflect scrutiny of its handling of the pandemic (Jacobs et al, 2020). Without any doubt, the politicisation of global health governance currently spearheaded by the WHO will be a major diplomatic legacy and hangover of the presently ravaging coronavirus pandemic. 
Global Economic Recession: With travel, tourism and international trade severely disrupted, and businesses across many industries shut down, COVID-19 has created a massive economic shock that is now hitting the international economic system with full force. Economist Kathy Bostjancic (2020), interviewed by Plugged In, was asked if coronavirus also means a global recession. She replied: "Yes, it's a foregone conclusion. As you reported, the U.S. and China are shutting down large portions of their economies... there's only so much you can take. Also, Europe now is also really struggling with COVID-19." This pandemic is not only ruthlessly claiming the lives of innocent people but has brought the entire world to an economic halt. Kristalina Georgieva, chief of the International Monetary Fund (IMF), has given an indication that the world has entered into recession (Crutsinger, 2020). To address this grave situation, a much stronger response is needed by all the nations to consider it as a global public health challenge in the form of a security threat. Without doubt, the world will have to grapple with economic downturns for some time to come.

Cyber/Digital Security Challenge: COVID-19 is no doubt throwing up a new vista of challenges in relations to the conduct of diplomacy and global politics. As the venue of diplomatic engagements transforms from the traditional face-to-face to virtual, there is the compelling challenge of ensuring cyber/digital space policing and security as sensitive data are being moved from 'safe environments' to 'unsafe environments'. While the assets that are traditionally considered to be part of the critical infrastructure remain important and need to protected, there is a new class of assets that must be protected and that were never thought of as critical infrastructure and were not designed with security in mind. A good example of such is the communication infrastructure especially new platforms like Zoom. While the sudden global shift to an online life has brought unprecedented changes to our social and work habits, it has also faced us with certain cyber security risks. Could the COVID-19 crisis lead to an increasingly insecure cyber world?

We don't know what impact the coronavirus pandemic will have or when it will end. There is talk of a "new normal," of "lessons learned," and new ways of doing business that will allow for the structural conditions that led to current circumstances to be addressed and for more compassionate societies to emerge. We must not lose sight of that imperative. But we aren't starting with a blank slate, and have many lessons learned and good practices to build on. Moreover, while virtual interactions will carry us through this period and even offer new opportunities going forward, they will often build on relationships that have been forged in person. So, when we eventually go back to conference rooms and to meeting our colleagues over coffee rather than through a screen, we should apply them to improving the effectiveness of the UN system and how we interact with it.

Rising Wave of Nationalism across the Globe: While the spread of the coronavirus clearly represents a massive challenge for humanity, the insidious rise of nationalism around the world is even more perturbing. It has been observed that global crises, such as the COVID-19 pandemic, tend to generally strengthen national sentiments as citizens put their trust in their national governments and states, which has the financial, organisational and emotional strengths that global institutions lack (El-Zomor and Yacoub, 2020). Reacting to the question on the legacies of the Coronavirus pandemic, Stephen M. Walt, professor of international relations at Harvard University, asserted thus:

The pandemic will strengthen the state and reinforce nationalism. Government of all types will adopt emergency measures to manage the crisis and many will loath to relinquish these new powers when the crisis is over... We will see a further retreat from hyperglobalization, as citizens 
look to national governments to protect and as states and firms seek to reduce further vulnerabilities. In short, COVID-19 will create a world that is less open, less prosperous and less free. (Stauffer, 2020).

Nationalism has also manifested itself in the form of anti-Chinese sentiments around the world. There are increasing calls for a full travel ban on Chinese visitors in many countries, particularly in Australia, South Korea, Japan, Hong Kong, Vietnam and EU countries. Even Chinese and other Asians in the United States have protested the rising spate of discrimination and racism against them (Kim, 2020). Yet within the European Union, there are well-founded fears that states' isolated responses to COVID-19 may unleash a wave of strong nationalism across Europe which could be one of the greatest tests for the European Union in recent years. Indeed, many European states consider the pandemic as a national emergency thereby weakening a coordinated action and response at the level of EU. With measures such as border closures, travel bans, and national distancing with Germany at the forefront, there may definitely develop a diplomatic row among the European states. Is this state of affairs not a reverse for globalism and internationalism?

China-centric World: Coronavirus is proving to be a power-changer. There have been speculations by experts and scholars that coronavirus pandemic could bring about a shift in power and reshape the global order in a fundamental way. Indeed, judging from containment efforts and response to the pandemic, Stephen Watt of Harvard University concluded that "COVID-19 will accelerate the shift in power and influence from West to East. South Korea and Singapore have responded best, and China has reacted well after its early mistakes. The response in Europe and America has been slow and haphazard by comparison, further tarnishing the aura of the Western "brand"' (Stauffer, 2020). This submission was reinforced by Kishore Mahbubani, who authored the book: Has China Won? The Chinese Challenge to American Primacy, when he said: "The COVID-19 pandemic will not fundamentally alter global economic directions. It will only accelerate a change that had already begun: a move away from U.S.-centric globalisation to a more China-centric globalisation" (Ibid.)

Already, China has successfully curbed the spread of the virus and has reopened its economy, while the U.S. and other European countries like Italy and Spain are churning out 'big' number of infections on a daily basis with strict lockdowns. Not that alone, China has emerged, in the midst of a global health emergency, as a friend to hard-hit countries around the globe. Under its 'white face' foreign policy strategy, China has started shipping medicines, protective equipment (essentially masks) and teams of doctors to several affected countries. Indeed, mask diplomacy and Health Silk Road have become cardinal components of China's grand strategy for its global dominance (Bali, 2020). Furthermore, the deployment of the pacesetting 5-G technology by China through its technology giant, Huawei has forced the U.S. and the West into playing 'catch up'. China's control of the all-important technology which is the next level in communication, strategic and economic spheres reinforces the idea that China will play an increasingly leading role in post COVID-19 world order.

\section{Conclusion}

The outbreak of the coronavirus pandemic in Wuhan, China late last year is one of the most dramatic and tragic incidents of the recent times. To be sure, no other singular development has had as much implication for the international system since the end of the cold war like the Covid19 pandemic. Expectedly and like every other global crisis, COVID-19 pandemic has attracted scholarly attention and generated a lot of academic studies. However, as an emerging and 
progressive phenomenon, no study on COVID-19 pandemic can yet be conclusive and definitive. They can at best, for now, be exploratory and empirical. One of such studies is this one. Coronavirus pandemic and the efforts being made to curb its rapidity and fatality bring to the fore a number of paradoxes. First, coronavirus pandemic is a global health crisis that requires concerted and coordinated response; yet, this period is marked by international travel bans, border closures and national distancing. Secondly, nationalism seems to be trumping internationalism as every country seems to be working for its own interest. Yet, much will not be achieved in the 'war against the virus' if international cooperation is not quickly sorted out. Finally, while the pandemic heralds a new order of international politics and diplomacy, it still sustains the old order of super power rivalry, competition and cooperation. That said, what is undeniable is that considering the legacies and impact of the coronavirus pandemic, the practice of diplomacy and international relations will not remain the same in the post COVID-19 world.

\section{References}

AFP News, 'EU Denies Softening Disinfo Report Under China Pressure', April 27, 2020. https://www.barrons.com/news/eu-denies-softening-disinfo-report-under-china-pressure01587996904.

Anderson and Aryes. (2015) "Economics of Influence: China and India in South Asia" Council on Foreign Relations. August 3. https://www.cfr.org/expert-brief/economics-influence-chinaand-india-south-asia

Bali, S. (2020). "Soft Power Diplomacy of China in third World Countries in the Times of COVID19". Magzter. http://www.magzter.com/article/News/Extraordinary-and-PlenipotentiaryDiplomatist/SOFT-POWER-DIPLOMACY-OF-CHINA-IN-THE-THIRD-WORLDCOUNTRIES-IN-THE-TIMES-OF-COVID-19

Boyd, A., Gatewood, J., Thorson, S. and Dye, T. (2019). “Data Diplomacy”. Science \& Diplomacy. Vol. 8, No. 1. May.

Briant R, US National Security Adviser made the remark in an interview with Morning Edition Host Steve Inskeep, April 21, 2020.

Crutsinger, M. (2020). "IMF head says global economy now in recession" ABC News March 27. https://abcnews.go.com/US/wireStory/imf-head-global-economy-now-recession69843184

Dubois, M., Wake, C., Sturridge, S. and Bennett, C. (2015). "The Ebola Response in West Africa: Exposing the politics and culture of international aid". HPG Working Paper, October 2015. https://www.odi.org/sites/odi.org.uk/files/odi-assets/publications-opinion-files/9903.pdf

Ekeruche, C. O. (2020). “The Case for debt relief in Africa amid COVID-19”. Africa Portal. April 14. https://www.africaportal.org/features/case-debt-relief-africa-amid-covid-19/.

El-Zomor, M. S. and Yacoub, A. R. (2020). "The Paradoxical Effect of COVID-19 on Globalisation." The Oxford University Politics Blog https://www.blog.politics.ox.ac.uk/theparadoxical-effect-of-covid-19-on-globalisation

European Data Portal. (2020). https://www.europeandataportal.eu/en 
Fin, N. C. (2020). "Diplomacy at the UN in the time of Coronavirus". IPI Global Observatory, April 6. https://theglobalobservatory.org/2020/04/diplomacy-at-un-in-time-of coronavirus/ Diplomacy at the UN in the Time of

Hamilton, J. M. (2020). Manipulating the Masses: Woodrow Wilson and the Birth of American Propaganda. Louisiana State University.

Jacobs, A., Shear, M. and Wong, E. (2020). "U.S.-China Feud Over Coronavirus Erupts at World Health Assembly." The New York Times May 18. https://www.nytimes.com/2020/05/18/health/coronavirus-who-china-trump.html

Jacobs, A., Shear, M. D. and Wong, E. (2020). "US - China Feud Over Coronavirus Erupts at World Health Assembly." The New York Times May 18. www.nytimes.com/202/05/18/health/coronavirus-who-china-trump.html

Jozuka, E. and Wang, S. (2020). "China and Japan's Relationship in thawing in the time of coronavirus". CNN February 26. https://edition.cnn.com/2020/02/25/asia/japan-chinacoronavirus-enemies-to-friends-hnk-intl/index.html

Kathy Bostjancic made this assertion when she was interviewed on a Voice of America television programme, Plugged In hosted by Greta Van Susteren https://www.voanews.com/media/2587636

Kim, H. (2020). "Fears of new virus trigger anti-China sentiment worldwide." Associated Press News http://apnews.com/04f18aafe1074a1c06b4203edcbdc661

Larsen and Gramer. (2020). "China Casts Itself as Global Saviour While U.S. and EU Focus on Virus at Home”. Foreign Policy. March 19. https://foreignpolicy.com/2020/03/19/china-us-eucoronavirus-great-power-competition/

Li, C. \& McEvleen, R. "Mask Diplomacy: How Coronavirus upended generations of China-Japan antagonism." Brookings. Mar 9, 2020. https://www.brookings.edu/blog/order-fromchaos/2020/03/09/mask-diplomacy-how-coronavirus-upended-generations-of-china-japanantagonism/

Lo, K. (2020). "Coronavirus: China donates another US\$30 million to WHO after US funding halt." South China Morning Post $29^{\text {th }}$ April www.scmp.com/news/china/diplomacy/article/3081280/coronavirus-china-donatesanother-us30-million-who-after-us

Manor, I. (2019). The Digitalization of Public Diplomacy. Palgrave Macmillan.

Nicolson, H. (1988). Diplomacy. New York: Oxford University Press.

Padelford, N. J. and Lincoln, G. A. (1963). The Dynamics of International Politics. New York: Macmillan Company.

Pelagidis, T. (2019). "China's Backdoor to Europe". Brookings. April 15, https://www.brookings.edu/blog/up-front/2019/04/15/chinas-backdoor-to-europe/

PM Modi's Remarks on Way Forward at Video Conference of SAARC Leaders on combating COVID. Press Release, Indian Prime Minister's Office, March 152020. https://pib.gov.in/PressReleaseIframePage.aspx?PRID=1606468\&RegID=3\&LID=1 
Ramsay, A. (2020). "There is nothing so political as a pandemic”. Open Democracy UK. March https://www.opendemocracy.net/en/opendemocracyuk/theres-nothing-so-political-as-apandemic/

Satow, E. (2011). A Guide to Diplomatic Practice. Vol. 1. London: Cambridge University Press.

Stauffer, B. (2020). "How the World Will Look After the Coronavirus Pandemic." Foreign Policy. March 2. https://foreignpolicy.com/2020/03/02/world-order-after-coronavirus-pandemic/

Tzu, S. (2005). The Art of War (First Edition). New Delhi: New Dawn Press Group.

US Office of Science and Technology Policy. (2020) https:/www.whitehouse.gov/ostp/

Wintour, P. (2020). "Dawn of Asian century puts pressure on Europe to choose sides: Diplomat." Gulf Times. July 19. https://m.gulf-times.com/story/664156/Dawn-of-Asian-century-putspressure-on-Europe-to-choose-sides-diplomat

Wong, B. (2020) ''How Chinese Nationalism is Changing'. The Diplomat. May 26. https://thediplomat.com/2020/05/how-chinese-nationalism-is-changing/

$\mathrm{Yu}$ and Kaene. (2020). 'China's mask diplomacy during coronavirus pandemic reveals its two global faces"'. The Print. April 5. https://theprint.in/world/chinas-mask-diplomacy-duringcoronavirus-pandemic-reveals-its-two-global-faces/394653/ 